\title{
Discovery of a new family of carbonic anhydrases in the malaria pathogen Plasmodium
} falciparum - the $\eta$-carbonic anhydrases

\section{Sonia Del Prete, ${ }^{\text {a }}$ Daniela Vullo, ${ }^{\mathrm{b}}$ Gillian M. Fisher, ${ }^{\mathrm{c}}$ Katherine T. Andrews, $^{\mathrm{c}}$ Sally-Ann Poulsen, ${ }^{c}$ Clemente Capasso, ${ }^{a^{*}}$ and Claudiu T. Supuran ${ }^{\mathrm{b}, \mathrm{d} *}$}

\author{
${ }^{a}$ Istituto di Bioscienze e Biorisorse (IBBR) - CNR, Via P. Castellino 111, 80131 Napoli, Italy. \\ ${ }^{b}$ Università degli Studi di Firenze, Polo Scientifico, Laboratorio di Chimica Bioinorganica, Rm. \\ 188, Via della Lastruccia 3, 50019 Sesto Fiorentino (Florence), Italy. \\ ${ }^{c}$ Eskitis Institute for Drug Discovery, Griffith University, Nathan, Queensland 4111, Australia. \\ ${ }^{\mathrm{d}}$ Università degli Studi di Firenze, Dipartimento Neurofarba, Sezione di Scienze Farmaceutiche, \\ Polo Scientifico, Sesto Fiorentino, Firenze, Italy.
}

\begin{abstract}
-Abstract: The genome of the protozoan parasite Plasmodium falciparum, the causative agent of the most lethal type of human malaria, contains a single gene annotated as encoding a carbonic anhydrases (CAs, EC 4.2.1.1), thought to belong to the $\alpha$-class. Here we demonstrate the kinetic properties of $\mathrm{PfCA}$ for the $\mathrm{CO}_{2}$ hydration reaction, as well as an inhibition study of this enzyme with inorganic and complex anions and other molecules known to interact with zinc proteins, including sulfamide, sulfamic acid, and phenylboronic/arsonic acids, detecting several low micromolar inhibitors. A closer examination of the sequence of this and the CA from other Plasmodium spp., as well as phylogenetic analysis, revealed that these protozoa encode for a yet undisclosed, new genetic family of CAs termed the $\eta$-CA class. The main features of the $\eta$-CAs are described in this report.
\end{abstract}

Keywords: carbonic anhydrase; $\eta$-CA-class enzyme; anion; inhibitor; Plasmodium falciparum

\footnotetext{
*Corresponding authors: Phone + 39-081-6132559; Fax +39-081-6132249; e-mail: c.capasso@ibp.cnr.it Phone: +39-055-4573005; Fax: +39-055-4573385; e-mail: claudiu.supuran@unifi.it.
} 
Carbonic anhydrases (CAs, EC 4.2.1.1) are metalloenzymes present in all life kingdoms, with five genetically distinct families described to date in various organisms. ${ }^{1-3}$ Most of them are zinc-containing enzymes, but Fe(II) may be present at the active site of the $\gamma$-CAs (described so far in Bacteria, Archaea and plants), whereas $\mathrm{Cd}(\mathrm{II})$ or $\mathrm{Zn}(\mathrm{II})$ ions seem to be equally effective for promoting catalysis in the $\zeta$-CAs (diatoms encode for this class of CAs). ${ }^{4-6}$ The metal ion is coordinated by three His residues (in the $\alpha$-, $\gamma$ - and $\delta$-class enzymes) or by one His, and two Cys residues (in the $\beta$ - and $\zeta$-CAs), with the fourth ligand being a water molecule/hydroxide ion. ${ }^{4-13}$ The main difference between these $\alpha$-, $\gamma$ - and $\delta$-class enzyme families where three His ligands coordinate to zinc, is the spacing between the three His residues in the protein sequence. For example, in all $\alpha$-CAs investigated so far the His ligands are at positions $x, x+2$ and $x+25$ (for example in the human isoform I, hCA I, these are His94, His96 and His119). ${ }^{1-3}$ For the $\gamma$-CAs the positions of His residues coordinating the metal ion are always $x, x+36$ and $x+41$, respectively, whereas for the $\delta$-CAs, the zinc ligands are positioned at residues $\mathrm{x}, \mathrm{x}+3$ and $\mathrm{x}+112$, respectively. ${ }^{1,4,5}$

CAs belonging to various classes have been cloned, purified and characterized from many pathogenic organisms such as bacteria, fungi and worms ${ }^{14-18}$ in order to investigate whether inhibition of such enzymes is crucial for their survival or pathogenesis. Indeed, for CAs from in most organisms it has been demonstrated that inhibitors belonging to the sulfonamide class (the most investigated CA inhibitors (CAIs)) ${ }^{1-4}$ interfere with the growth, possessing interesting antiinfective properties. ${ }^{19-22}$

Few protozoan parasites have been investigated for the presence and druggability of CAs up until now. The causative agent of human malaria,- Plasmodium falciparum, was one of the first ene to be investigated. ${ }^{23-25}$ A truncated form of the P. falciparum CA gene was cloned, expressed and purified in 2004 by Krungkrai's group, ${ }^{23 a}$ who showed that it is an active enzyme, possessing a good esterase activity with 4-nitrophenylacetate as a substrate, and also was inhibited by known sulfonamide-based CA inhibitors such as acetazolamide. The same authors concluded that the enzyme belongs to the $\alpha$-class of CAs. ${ }^{23 a}$ Subsequent studies from Krungkrai's and our laboratories showed that different Plasmodium spp. encode CAs, all considered to belong to the $\alpha$-class, and that primary sulfonamides inhibited in vitro and in vivo growth of Plasmodium parasite. ${ }^{23 \mathrm{~b}-25}$ The $P$. falciparum CA, the only Plasmodium CA investigated to date, has been denominated PfCA. ${ }^{23}$ Some benzenesulfonamide derivatives showed effective in vitro inhibition of the esterase activity of PfCA, and also inhibited the in vitro growth of the parasite. ${ }^{23 b-25}$ Furthermore, some of these sulfonamides were effective as antimalarial agents in mice infected with P. berghei, an animal model of human malaria infection, with an efficacy similar to that of the clinically used drug chloroquine. ${ }^{24}$ CAIs 
were considered to possess antiantimalarial activity because their inhibition of the first step of pyrimidine nucleotide biosynthesis in the protozoan parasite, i.e., the CA-mediated carbamoylphosphate biosynthetic pathway. ${ }^{24}$ However, this has not been experimentally confirmed and $P f C A$ has never been investigated for its catalytic activity with $\mathrm{CO}_{2}$ as substrate up until now.

More recently, an $\alpha$-CA has also been cloned and characterized in another unicellular

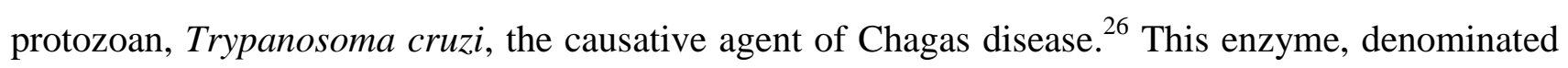
TcCA, had a high catalytic activity for the $\mathrm{CO}_{2}$ hydration reaction, although it is devoid of the His64 proton shuttle, an amino acid residue involved in the catalytic cycle of $\alpha$-CAs. ${ }^{1-3,26}$ The thiols, another class of CAIs, were the most potent in vitro inhibitors of $T c \mathrm{CA}\left(\mathrm{K}_{\mathrm{I}} \mathrm{S}\right.$ of 21.1-79.0 nM) and some of them also inhibited the epimastigotes growth of two T. cruzi strains in vivo. ${ }^{26}$ Thus, protozoan $\mathrm{CA}$ inhibition may be a valid strategy to control infection with protozoans causing diseases such as malaria and Chagas disease. ${ }^{24,26}$

Anions constitute another important class of CAIs. ${ }^{27-30}$ As there are no anion inhibition studies of PfCA, here we undertook such an investigation, including in our study the common metal-complexing anions, the halides and pseudohalides, as well as some complex anions and small molecules known to interact with these enzymes, such as sulfamide, sulfamic acid, phenylboronic acid, diethyldithiocarbamate, etc. ${ }^{31}$ Up until this study, it should be noted that the catalytic activity of PfCA had only been investigated for the esterase reaction catalyzed by the enzyme, with 4nitrophenylacetate as a substrate. ${ }^{24}$ Here we present the first kinetic study of the $\mathrm{CO}_{2}$ hydrase properties of this enzyme, together with the anion inhibition data mentioned above. As discussed above, based on amino acid sequence comparisons, Plasmodium CA enzymes have until now been classified as members of the $\alpha$-CA family. A closer look at the amino acid sequence and phylogeny of CAs present in P. falciparum and other Plasmodium spp., led us to the conclusion that PfCA was erroneously assigned as being an $\alpha$-class enzyme. Here we propose that Plasmodia encode for CAs belonging to a new genetic family that we call the $\eta-C A$ class.

Figs. 1 -3 here

The PfCA full length enzyme contains 600 amino acid residues (PlasmoDB: PF3D7_1140000), in contrast to hCA I and II which have 260 and 259 residues, respectively. ${ }^{25}$ An alignment of the amino acid sequences of a truncated ${ }^{23 a}$ PfCA sequence, with the two human $\alpha$ CAs, hCA I and II, is shown in Fig. 1, in order to identify some features of the protozoan enzyme previously assigned to the $\alpha$-class. ${ }^{23 b}$ The sequence of -truncated PfCA sequence can be aligned to that of hCA I and II, but only if gaps are added to in the amino acid sequence regions in which the zinc coordinating histidines are located: six gaps must be placed in the PfCA sequence (after residue 96 - the hCA I numbering system is used throughout the paper), and five gaps in the hCA 
I/II sequences (after Leu118). However, we consider this as to be a "forced" alignment that has erroneously led to the assignment of PfCA as belonging to the $\alpha$-class. Indeed, the sequence alignment of Fig. 1 demonstrates that other features of $\alpha$-CAs are not present in the PfCA sequence, such as the proton shuttling residue in position 64 (His in most, but not all $\alpha$-CAs, but Gln in PfCA), or the Thr199 residue. The dyad Glu106 - Thr199 is conserved in all $\alpha$-CAs investigated so far, being involved in the orientation of the substrate for the nucleophilic attack by the zinc hydroxide species of the enzyme. ${ }^{1-4}$ It may be observed that the side chain of Lys present in position 199 in the PfCA sequence in the forced alignment would be too bulky for assuring the correct hydrogen bonding network with Glu106, when $\mathrm{CO}_{2}$ is bound in the hydrophobic pocket of $\alpha$-CAs. ${ }^{2}$ All these features of PfCA which are not typical of an $\alpha$-class enzyme, prompted us to compare the sequences of other Plasmodium spp CAs. An alignment of CA sequences available in the Plasmodium genome database, as well as Plasmodium reichenowi and Plasmodium vinckei sequences, is shown in Fig. 2. ${ }^{32}$ These alignment data indicate that the CAs present in these protozoa are not $\alpha$-CAs, and that they belong to a yet undescribed, new CA genetic family, for which we propose the name $\eta-\mathrm{CA}$. The main features of this new enzyme class are as follows:

(i) the predicted metal ion coordinating residues are His94, His96 and His118 (again the hCA I numbering system is used for allowing us to better describe the differences between the $\alpha$ - and $\eta$ CAs). Thus, the metal ion coordination pattern $(x, x+2, x+25$ in $\alpha-C A s)$ is $x, x+2, x+24$, for the $\eta-$ CAs. For the first four Plasmodium species shown in the alignment in Fig. 2, which include three $P$. falciparum lines and the chimpanzee malaria parasite $P$. reichenowi which is phylogenetically related to the human parasite $P$. falciparum, the same putative zinc coordination pattern is observed whereas for the other last four sequences, which are all murine malaria parasite species, His94 is replaced by an Asn, which cannot coordinate $\mathrm{Zn}(\mathrm{II})$. However, in the murine Plasmodia four sequences there are two other His residues, in position 91 and 92 (conserved in all these four CAs), which in principle could coordinate $\mathrm{Zn}$ (II). However, this may represent another genetic CA family (proposed to be denominated $\theta-\mathrm{CA}$ class). Alternatively, similar to the CA-related proteins (CARPs), ${ }^{33}$ these four proteins may lack one of the $\mathrm{Zn}$ (II) ligands, being catalytically inactive $\eta$ class enzymes. The hypothesis as to whether there is a seventh CA genetic family (considering the $\eta$-CA class as the sixth one) may be confirmed or refuted only when one of these enzymes is cloned and the presence or absence of $\mathrm{CO}_{2}$ hydrase activity verified;

(ii) the $\eta$-CAs do not have His in position 64 (a major difference compared to $\alpha$-CAs). In all sequences of Fig. 2, Phe is present in that position;

(iii) the Glu106 - Thr199 dyad, present in all $\alpha$-CAs, is also absent in the $\eta$-CAs, with Ser being present in both these positions (Fig. 2); 
(iv) the $\eta$-CAs discovered so far have a much longer amino acid sequence compared to the $\alpha$-CAs, which typically are 250-280 amino acid residues long enzymes. It may be observed that the $\eta$-class enzymes have $>400$ amino acid residues in their sequence. However it should be noted that on average Plasmodium gene sequences, excluding introns, are larger than those of other organisms. ${ }^{34}$

These conclusions were also reinforced when the phylogenetic analysis shown in Fig. 3 was performed. Enzymes from all CA families and all types of prokaryotes and eukaryotes have been included in the analysis (Fig. 3). It may be observed that the enzymes belonging to the $\delta$-, $\alpha$ - and $\eta$ CA classes clustered together on the upper part of the tree. There are two main branches, one encompassing all the $\delta$-CAs, and the second one with $\alpha$ - and $\eta$-CAs. The prokaryotic $\alpha$-CAs are more distantly related to the eukaryotic enzymes as well as to the $\eta$-class enzymes. Among these, CAs from the human or chimpanzee infecting Plasmodium species that have the three His ligands (positions 94, 96 and 118) all cluster in the upper part of the branch, whereas the murine Plasmodium CAs without His94 cluster in the lower part of the phylogenetic tree. Thus, the $\eta-C A$ class seems to be the most recent genetic family of such enzymes, being genetically closer to the eukaryotic $\alpha$-CAs. The $\gamma$-CAs are also phylogenetically related to these three CA genetic families, their branch being the closest to the one that led to $\delta$-, $\alpha$ - and $\eta$-CAs. It should be recalled that all these four genetic families have the metal ion coordinated by three His residues. On the other hand, on the lower branches of the tree are found the $\beta$ - and $\zeta$-CAs, which have the $\mathrm{Zn}(\mathrm{II})$ ion coordinated by two Cys and one His residue. The $\beta$-CAs from various organisms are, as expected, more related to each other than with the $\zeta$-class enzymes which are on the lowest branch of the tree.

Tables 1 and 2 here

To begin to understand the enzymatic characteristics of $P f C A$, we next measured the $\mathrm{CO}_{2}$ hydrase activity of this recombinant enzyme by a stopped-flow assay. ${ }^{28}$ Data in Table 1 , where enzymes belonging to all six CA families are included, show that $P f C A$ has a good $\mathrm{CO}_{2}$ hydrase activity at $\mathrm{pH} 7.5$, with a $\mathrm{k}_{\mathrm{cat}}$ of $1.4 \times 10^{5} \mathrm{~s}^{-1}$ and a $\mathrm{k}_{\mathrm{cat}} / \mathrm{K}_{\mathrm{M}}$ of $5.4 \times 10^{6} \mathrm{M}^{-1} \mathrm{x} \mathrm{s}^{-1}$. Furthermore, this activity is inhibited by the clinically used sulfonamide acetazolamide (as for all other classes of CAs), with an inhibition constant of $170 \mathrm{nM}$. Thus, PfCA is among the least effective catalysts shown in Table 1, being around 27.5 - 28 times less efficient compared to hCA II ( $\alpha$-class) or ZnCA1-R1 ( $\zeta$-class CA), which are among the enzymes with the highest turnover numbers described so far. ${ }^{1,6}$ The $\eta$-class enzyme shows however a significant catalytic action, as its kinetic parameters are of the same order of magnitude as those of FbiCA ( $\beta$-CA from the plant Flaveria bidentis) or TweCA ( $\delta$-CA from the diatom Thalassiosira weissflogii).

We next investigated the anion inhibition profile of recombinant PfCA with simple and complex anions, as well as small molecules known to inhibit other CA families (Table 2). For 
comparison, we have also included the anion inhibition data of the two human enzymes hCA I and II as well as the protozoan T. cruzi enzyme TcCA, all of which belong to the $\alpha$-CAs and as reported earlier by us. ${ }^{35}$ The following should be noted regarding the inhibition data of Table 2 :

(i) Perchlorate, tetrafluoroborate and hydrogensulfite were not inhibitors of PfCA, a behavior observed with most other $\alpha$ - and $\beta$-CAs investigated so far for perchlorate and tetrafluoroborate, but not for hydrogensulfite, which is an effective (submillimolar) TcCA inhibitor. ${ }^{27}$

(ii) A number of the investigated anions showed weak potency of inhibition against PfCA, with inhibition constants ranging between 2.24 and $9.76 \mathrm{mM}$ (Table 2). They include the halides (fluoride, chloride, bromide and iodide), azide, bicarbonate, nitrite, tellurate, perosmate, divanadate, tetraborate, perrhenate, perruthenate, peroxydisulfate, trithiocarbonate, triflate, sulfate, fluorosulfonate and iminodisulfonate. It is notable that for the halides the least efficient inhibitor was chloride, and the inhibition power increased with the increase atomic weight of the halogen, from chloride to iodide. Fluoride was slightly more inhibitory than bromide. However there is a very important difference in the inhibition profile by halides of the two protozoan enzymes, with TcCA-being much more sensitive to these anions than PfCA.

(iii) More effective PfCA inhibitors detected here were cyanate, thiocyanate, cyanide, bicarbonate, carbonate, nitrate, hydrogensulfide, stannate, selenite, selenocyanide and diethylditiocarbamate, which showed inhibition constants in the range of $0.55-0.95 \mathrm{mM}$ (Table 2). Some interesting correlations between the nature of the anion and its inhibitory activity against PfCA are now apparent. For example, for the pseudohalides, such as cyanate, thiocyanate, cyanide, are generally inhibitory against many metalloenzymes, and this is also the case for $P f C A{ }^{1-6}$ It is well known that these anions readily complex cations in solution or within the enzyme active sites. In fact many of them efficiently inhibit $\alpha$-CAs such as hCA I/II or TcCA (Table 2). A very interesting case is constituted by bicarbonate/carbonate, which are rather inhibitory against PfCA (and TcCA) and much less so against the human isoforms hCA I and II. The opposite was observed for trithiocarbonate, which is an effective, micromolar inhibitor of hCA I, II and TcCA and a quite weak PfCA inhibitor. Nitrate on the other hand is also a rather effective inhibitor of the protozoan enzymes but not of the human ones. Diethyldithiocarbamate, which contains the same zinc-binding function as trithiocarbonate, was on the other hand a much more effective PfCA inhibitor.

(iv) The best PfCA inhibitors detected here were sulfamide $\left(\mathrm{H}_{2} \mathrm{NSO}_{2} \mathrm{NH}_{2}\right)$, sulfamic acid $\left(\mathrm{H}_{2} \mathrm{NSO}_{3} \mathrm{H}\right)$, phenylboronic acid $\left(\mathrm{Ph}-\mathrm{B}(\mathrm{OH})_{2}\right)$ and phenylarsonic acid $\left(\mathrm{Ph}-\mathrm{AsO}_{3} \mathrm{H}_{2}\right)$, which had inhibition constants in the low micromolar range $\left(\mathrm{K}_{\mathrm{IS}}\right.$ of 6-9 $\left.\mu \mathrm{M}\right)$. All four compounds are much more effective $\eta$-CA inhibitors than $\alpha$-CA inhibitors, for which millimolar affinities of these inhibitors were measured, Table 2. 
(v) The inhibition profile of the protozoan enzyme PfCA is very different from that of the human enzymes (hCA I and II) and also the T. cruzi TcCA, which is probably due to the fact that the active sites of the $\eta$ - and $\alpha$-class CAs are probably quite different.

As for most anions, it is probable that these inhibitors bind to the metal ion from the $\eta-C A$ active site, in tetrahedral or trigonal-bipyramidal geometries of the $\mathrm{Zn}$ (II).

In conclusion, we demonstrated that $P f C A$, an enzyme considered earlier to belong to the $\alpha$-CA class, has significant $\mathrm{CO}_{2}$ hydrase activity, with a $\mathrm{k}_{\mathrm{cat}}$ of $1.4 \times 10^{5} \mathrm{~s}^{-1}$ and a $\mathrm{k}_{\mathrm{cat}} / \mathrm{K}_{\mathrm{M}}$ of $5.4 \times 10^{6} \mathrm{M}^{-1}$ $\mathrm{x} \mathrm{s}^{-1}$. The sequence of this and annotated CAs from other Plasmodium spp., as well as their phylogenetic analysis, allowed us to conclude that these protozoa encode for a yet undisclosed, new genetic family of CAs, which was called the $\eta$-CA class. The main features of the $\eta$-CAs are also delineated here. We also evaluated a series of inorganic simple/complex anions and other small molecules known to bind to metalloenzymes (sulfamide, sulfamic acid, phenylboronic/arsonic acids), for the inhibition of PfCA, detecting several low micromolar inhibitors however with a differing inhibition profile to a-CAs.

Acknowledgments: This research was financed by an FP7 EU project (Dynano) to CTS, the Australian Research Council (FT0991213 to KTA, FT10100185 to S-AP) and the Australian National Health and Medical Research Council (PhD Scholarship to GF). 


\section{References and Notes}

1. Alterio, V.; Di Fiore, A.; D'Ambrosio, K.; Supuran, C. T.; De Simone, G. Chem. Rev. 2012, $112,4421$.

2. Domsic, J. F.; Avvaru, B. S.; Kim, C. U.; Gruner, S. M.; Agbandje-McKenna, M.; Silverman, D. N.; McKenna, R. J. Biol. Chem. 2008, 283, 30766.

3. Supuran, C. T. Nature Rev. Drug Discov. 2008, 7, 168.

4. a) Supuran, C. T. Front. Pharmacol. 2011, 2, 34; b) Del Prete, S.; Vullo, D.; Scozzafava, A.; Capasso, C.; Supuran, C.T. Bioorg Med. Chem. 2014, 22, 531; c) Vullo, D.; Del Prete, S.; Osman, S.M.; De Luca, V.; Scozzafava, A.; AlOthman, Z.; Supuran, C.T.; Capasso, C. Bioorg Med. Chem. Lett. 2014, 24, 275.

5. a) Ferry, J.F. Biochim. Biophys. Acta 2010, 1804, 374; b) Smith, K.S.; Jakubzick, C.; Whittam, T.S.; Ferry, J.G. Proc Natl Acad Sci U S A. 1999, 96, 15184; c) Zimmerman, S.A.; Tomb, J.F.; Ferry, J.G. J. Bacteriol. 2010, 192, 1353; d) Zimmerman, S.A.; Ferry, J.G.; Supuran, C.T. Curr. Top. Med. Chem. 2007, 7, 901 ; e) Tripp, B. C.; Bell, C. B., 3rd; Cruz, F.; Krebs, C.; Ferry, J. G. J. Biol. Chem. 2004, 279, 6683.

6. a) Xu, Y.; Feng, L.; Jeffrey, P. D.; Shi, Y.; Morel, F. M. Nature 2008, 452, 56; b) Alterio, V.; Langella, E.; Viparelli, F.; Vullo, D.; Ascione, G.; Dathan, N.A.; Morel, F.M.; Supuran, C.T.; De Simone, G.; Monti, S.M. Biochimie 2012, 94, 1232; c) Viparelli, F.; Monti, S.M.; De Simone, G.; Innocenti, A.; Scozzafava, A.; Xu, Y.; Morel, F.M.; Supuran, C.T. Bioorg. Med. Chem. Lett. 2010, 20, 4745.

7. a) Alterio, V.; Hilvo, M.; Di Fiore, A.; Supuran, C. T.; Pan, P.; Parkkila, S.; Scaloni, A.; Pastorek, J.; Pastorekova, S.; Pedone, C.; Scozzafava, A.; Monti, S. M.; De Simone, G. Proc. Natl. Acad. Sci. USA 2009, 106, 16233; b) Vullo, D.; De Luca, V.; Scozzafava, A.; Carginale, V.; Rossi, M.; Supuran, C.T.; Capasso, C. Bioorg. Med. Chem. Lett. 2012, 22, 6324.

8. a) Neri, D.; Supuran, C. T. Nature Rev. Drug Discov. 2011, 10, 767; b) Supuran, C. T. J. Enzyme Inhib. Med. Chem. 2012, 27, 759.

9. Schlicker, C.; Hall, R. A.; Vullo, D.; Middelhaufe, S.; Gertz, M.; Supuran, C. T.; Muhlschlegel, F. A.; Steegborn, C. J. Mol. Biol. 2009, 385, 1207-1214.

10. a) Monti, S.M.; De Simone, G.; Dathan, N.A.; Ludwig, M.; Vullo, D.; Scozzafava, A.; Capasso, C.; Supuran, C.T. Bioorg. Med. Chem. Lett. 2013, 23, 1626; b) Suarez Covarrubias, A.; Larsson, A. M.; Hogbom, M.; Lindberg, J.; Bergfors, T.; Bjorkelid, C.; Mowbray, S. L.; Unge, T.; Jones, T. A. J. Biol. Chem. 2005, 280, 18782.

11. a) Tu, C.; Tripp, B. C.; Ferry, J. G.; Silverman, D. N. J. Am. Chem. Soc. 2001, 123, 5861; b) Del Prete, S.; Vullo, D.; De Luca, V.; Carginale, V.; Scozzafava, A.; Supuran, C.T.; Capasso, Bioorg. Med. Chem. Lett. 2013, 23, 4067.

12. Covarrubias, A. S.; Bergfors, T.; Jones, T. A.; Hogbom, M. J. Biol. Chem. 2006, 281, 4993.

13. Supuran, C. T. Bioorg. Med. Chem. Lett. 2010, 20, 3467.

14. Burghout, P.; Vullo, D.; Scozzafava, A.; Hermans, P. W.; Supuran, C. T. Med. Chem. 2011, 19, 243.

15. Joseph, P.; Ouahrani-Bettache, S.; Montero, J. L.; Nishimori, I.; Minakuchi, T.; Vullo, D.; Scozzafava, A.; Winum, J. Y.; Kohler, S.; Supuran, C. T. Med. Chem. 2011, 19, 1172.

16. Joseph, P.; Turtaut, F.; Ouahrani-Bettache, S.; Montero, J. L.; Nishimori, I.; Minakuchi, T.; Vullo, D.; Scozzafava, A.; Kohler, S.; Winum, J. Y.; Supuran, C. T. J. Med. Chem. 2010, 53, 2277.

17. Nishimori, I.; Minakuchi, T.; Morimoto, K.; Sano, S.; Onishi, S.; Takeuchi, H.; Vullo, D.; Scozzafava, A.; Supuran, C. T. J. Med. Chem. 2006, 49, 2117.

18. Nishimori, I.; Minakuchi, T.; Vullo, D.; Scozzafava, A.; Innocenti, A.; Supuran, C. T. J. Med. Chem. 2009, 52, 3116.

19. a) Supuran, C. T. Curr. Pharm. Des. 2010, 16, 3233; b) Carta, F.; Aggarwal, M.; Maresca, A.; Scozzafava, A.; McKenna, R.; Masini, E.; Supuran, C. T. J. Med. Chem. 2012, 55, 1721. 
20. a) Supuran, C. T.; Scozzafava, A.; Casini, A. Med. Res. Rev. 2003, 23, 146; b) Del Prete, S.; Isik, S.; Vullo, D.; De Luca, V.; Carginale, V.; Scozzafava, A.; Supuran, C. T.; Capasso, C. J. Med. Chem. 2012, 55, 10742; c) Capasso, C.; Supuran, C.T. Expert Opin. Ther. Pat. 2013, 23, 693.

21. Vullo, D.; Nishimori, I.; Scozzafava, A.; Kohler, S.; Winum, J. Y.; Supuran, C. T. Bioorg. Med. Chem. Lett. 2010, 20, 2178.

22. Winum, J. Y.; Kohler, S.; Supuran, C. T. Curr. Pharm. Des. 2010, 16, 3310-3316.

23. a) Reungprapavut, S.; Krungkrai, S. R.; Krungkrai, J. J. Enzyme Inhib. 2004, 19, 249; b) Krungkrai, J.; Krungkrai, S. R.; Supuran, C. T. Curr. Top. Med. Chem. 2007, 7, 909.

24. Krungkrai, J.; Krungkrai, S. R.; Supuran, C. T. Bioorg. Med. Chem. Lett. 2008, 18, 5466.

25. a) Krungkrai, J.; Supuran, C. T. Curr. Pharm. Des. 2008, 14, 631. b) Andrews, K.T.; Fisher, G.M.; Sumanadasa, S.D.M.; Sinner-Adams, T.; Moeker, J.; Lopez, M.; Poulsen, S.-A. Bioorg. Med. Chem. Lett. 2013, 23, 455; c) Fisher, G.M.; Tanpure, R.P.; Douchez, A.; Andrews, K.T.; Poulsen, S.-A. Chem. Biol. Drug Des. 2014, doi: 10.1111/cbdd.12335

26. Pan, P.; Vermelho, A. B.; Capaci Rodrigues, G.; Scozzafava, A.; Tolvanen, M. E.; Parkkila, S.; Capasso, C.; Supuran, C. T. J. Med. Chem. 2013, 56, 1761.

27. De Simone, G.; Supuran, C. T. J. Inorg. Biochem. 2012, 111, 117.

28. Khalifah, R. G. J. Biol. Chem. 1971, 246, 2561. An Applied Photophysics stopped-flow instrument has been used for assaying the $\mathrm{CA}$ catalyzed $\mathrm{CO}_{2}$ hydration activity. Phenol red (at a concentration of $0.2 \mathrm{mM}$ ) has been used as indicator, working at the absorbance maximum of $557 \mathrm{~nm}$, with $10-20 \mathrm{mM}$ Hepes (pH 7.5) as buffer, and $20 \mathrm{mM} \mathrm{Na}_{2} \mathrm{SO}_{4}$ or $20 \mathrm{mM} \mathrm{NaBF}_{4}$ for maintaining constant the ionic strength, following the initial rates of the CA-catalyzed $\mathrm{CO}_{2}$ hydration reaction for a period of 10-100 s. The $\mathrm{CO}_{2}$ concentrations ranged from 1.7 to $17 \mathrm{mM}$ for the determination of the kinetic parameters and inhibition constants. For each inhibitor at least six traces of the initial 5-10\% of the reaction have been used for determining the initial velocity. The uncatalyzed rates were determined in the same manner and subtracted from the total observed rates. Stock solutions of inhibitor $(10 \mathrm{mM})$ were prepared in distilleddeionized water and dilutions up to $0.01 \mu \mathrm{M}$ were done thereafter with distilled-deionized water. Inhibitor and enzyme solutions were preincubated together for $15 \mathrm{~min}$ at room temperature prior to assay, in order to allow for the formation of the E-I complex. The inhibition constants were obtained by non-linear least-squares methods using the ChengPrusoff equation whereas the kinetic parameters for the uninhibited enzymes from Lineweaver-Burk plots, as reported earlier, ${ }^{29-31}$ and represent the mean from at least three different determinations.

29. a) Innocenti, A.; Scozzafava, A.; Supuran, C. T. Bioorg. Med. Chem. Lett. 2009, 19, 1855;

b) Innocenti, A.; Scozzafava, A.; Supuran, C. T. Bioorg. Med. Chem. Lett. 2010, 20, 1548.

30. a) Kolayli, S.; Karahalil, F.; Sahin, H.; Dincer, B.; Supuran, C. T. J. Enzyme Inhib. Med. Chem. 2011, 26, 895; b)Maresca, A.; Scozzafava, A.; Kohler, S.; Winum, J. Y.; Supuran, C. T. J. Inorg. Biochem. 2012, 110, 36; c)Ozensoy, O.; Arslan, M.; Supuran, C. T. J. Enzyme Inhib. Med. Chem. 2011, 26, 749; d) Temperini, C.; Scozzafava, A.; Supuran, C. T. Bioorg. Med. Chem. Lett. 2010, 20, 474.

31. a) Carta, F.; Aggarwal, M.; Maresca, A.; Scozzafava, A.; McKenna, R.; Supuran, C. T. Chem. Commun. 2012, 48, 1868; b) Maresca, A.; Carta, F.; Vullo, D.; Supuran, C. T. J. Enzyme Inhib. Med. Chem. 2013, 28, 407.

32. Aurrecoechea C, Brestelli J, Brunk BP, Dommer J, Fischer S, Gajria B, Gao X, Gingle A, Grant G, Harb OS, Heiges M, Innamorato F, Iodice J, Kissinger JC, Kraemer E, Li W, Miller JA, Nayak V, Pennington C, Pinney DF, Roos DS, Ross C, Stoeckert CJ Jr, Treatman C, Wang H. Nucleic Acids Res. 2009, 37(Database issue):D539-43. Epub 2008 Oct 28.

33. Nishimori, I.; Vullo, D.; Minakuchi, T.; Scozzzafava, A.; Capasso, C.; Supuran, C.T. Bioorg. Med. Chem. Lett. 2013, 23, 256. 
34. Gardner MJ, Hall N, Fung E, White O, Berriman M, Hyman RW, Carlton JM, Pain A, Nelson KE, Bowman S, Paulsen IT, James K, Eisen JA, Rutherford K, Salzberg SL, Craig A, Kyes S, Chan MS, Nene V, Shallom SJ, Suh B, Peterson J, Angiuoli S, Pertea M, Allen J, Selengut J, Haft D, Mather MW, Vaidya AB, Martin DM, Fairlamb AH, Fraunholz MJ, Roos DS, Ralph SA, McFadden GI, Cummings LM, Subramanian GM, Mungall C, Venter JC, Carucci DJ, Hoffman SL, Newbold C, Davis RW, Fraser CM, Barrell B. Nature 2002 3;419(6906), 498.

35. Pan, P.; Vermelho, A.B.; Scozzafava, A.; Parkkila, S.; Capasso, C.; Supuran, C.T. Bioorg. Med. Chem. 2013, 21, 4472. 
Table 1. Kinetic parameters for the $\mathrm{CO}_{2}$ hydration reaction catalysed by various CAs belonging to the various families. ${ }^{1-7}$ The $\alpha$-class CAs were the human cytosolic isozymes hCA I and II and the bacterial SazCA (from Sulfurihydrogenibium azorense). ${ }^{5 \mathrm{~d}, 6}$ The $\beta$-class includes the fungal enzyme Can 2 from Cryptococcus neoformans ${ }^{4 \mathrm{~b}}$ and FbiCA1 from the plant Flaveria bidentis. ${ }^{18}$ The $\gamma$-class enzyme was PgiCA from the anaerobic bacterium Porphyromonas gingivalis, ${ }^{19}$ whereas the $\delta$ and $\zeta$ class enzymes ${ }^{2,9}$ (the last with zinc and cadmium at the active site) were from the diatom Thalassiosira weissflogii. Inhibition data with the clinically used sulfonamide acetazolamide (5acetamido-1,3,4-thiadiazole-2-sulfonamide) are also provided. All data were obtained in the author's laboratories.

\begin{tabular}{|c|c|c|c|c|c|}
\hline Isozyme & Class & Organism & $\begin{array}{l}\mathrm{k}_{\mathrm{cat}} \\
\left(\mathrm{s}^{-1}\right)\end{array}$ & $\begin{array}{l}\mathrm{k}_{\mathrm{cat}} / \mathrm{K}_{\mathrm{m}} \\
\left(\mathrm{M}^{-1} \cdot \mathrm{s}^{-1}\right)\end{array}$ & $\begin{array}{c}\mathrm{K}_{\mathrm{I}} \text { (acetazolamide) } \\
(\mathrm{nM})\end{array}$ \\
\hline$\overline{\mathrm{hCA} \mathrm{I}}{ }^{\mathrm{a}}$ & $\alpha$ & human & $2.0 \times 10^{5}$ & $5.0 \times 10^{7}$ & 250 \\
\hline $\mathrm{hCA} \mathrm{II}^{\mathrm{a}}$ & $\alpha$ & human & $1.4 \times 10^{6}$ & $1.5 \times 10^{8}$ & 12 \\
\hline $\mathrm{SazCA}^{\mathrm{b}}$ & $\alpha$ & bacterium & $4.4 \times 10^{6}$ & $3.5 \times 10^{8}$ & 0.9 \\
\hline $\operatorname{Can} 2^{c}$ & $\beta$ & fungus & $3.9 \times 10^{5}$ & $4.3 \times 10^{7}$ & 10.5 \\
\hline FbiCA1 ${ }^{\mathrm{d}}$ & $\beta$ & plant & $1.2 \times 10^{5}$ & $7.5 \times 10^{6}$ & 27 \\
\hline $\mathrm{PgiCA}^{\mathrm{e}}$ & $\gamma$ & bacterium & $4.1 \times 10^{5}$ & $5.4 \times 10^{7}$ & 324 \\
\hline CdCA1-R ${ }^{\mathrm{f}}$ & $\zeta$ & diatom & $1.5 \times 10^{6}$ & $1.4 \times 10^{8}$ & 82 \\
\hline $\mathrm{ZnCA} 1-\mathrm{R} 1^{\mathrm{f}}$ & $\zeta$ & diatom & $1.4 \times 10^{6}$ & $1.6 \times 10^{8}$ & 58 \\
\hline TweCA $^{g}$ & $\delta$ & diatom & $1.3 \times 10^{5}$ & $3.3 \times 10^{7}$ & 83 \\
\hline$P f \mathrm{CA}^{\mathrm{h}} \eta$ & \multicolumn{2}{|c|}{ protozoa } & \multicolumn{2}{|c|}{$5.4 \times 10^{6}$} & 170 \\
\hline
\end{tabular}

${ }^{\text {a }}$ Data from ref. ${ }^{1}$

${ }^{\mathrm{b}}$ Data from ref. ${ }^{7 \mathrm{~b}}$

${ }^{\mathrm{c}}$ Data from ref. ${ }^{9}$

${ }^{\mathrm{d}}$ Data from ref. ${ }^{10 \mathrm{a}}$

${ }^{\mathrm{e}}$ Data from ref. ${ }^{11 \mathrm{~b}}$

${ }^{\mathrm{f}}$ Data from ref. ${ }^{6}$

${ }^{\mathrm{g}}$ Data from ref. ${ }^{4 \mathrm{~b}}$

${ }^{\mathrm{h}}$ This work. 
Table 2: Inhibition constants of anion inhibitors against $\alpha$-CAs from mammals (hCA I, and II, human isoforms, and the protozoan enzyme from T. cruzi, TcCA), and the $\eta$-CA PfCA from $P$. falciparum, for the $\mathrm{CO}_{2}$ hydration reaction, at $20{ }^{\circ} \mathrm{C}$ and $\mathrm{pH} 7.5 .^{28}$

\begin{tabular}{|c|c|c|c|c|}
\hline \multirow[t]{2}{*}{ Inhibitor $^{\S}$} & \multicolumn{3}{|c|}{$\mathrm{K}_{\mathrm{I}}[\mathrm{mM}]^{\#}$} & \multirow[b]{2}{*}{$P f \mathrm{CA}^{\mathrm{c}}$} \\
\hline & $\mathrm{hCA} \mathrm{I}^{\mathrm{a}}$ & $\mathrm{hCA} \mathrm{II}{ }^{\mathrm{a}}$ & $\mathrm{TcCA}^{\mathrm{b}}$ & \\
\hline$\overline{\mathrm{F}^{-}}$ & $>300$ & $>300$ & 0.90 & 5.78 \\
\hline $\mathrm{Cl}^{-}$ & 6 & 200 & 0.81 & 9.76 \\
\hline $\mathrm{Br}^{-}$ & 4 & 63 & 0.73 & 6.05 \\
\hline $\mathrm{I}^{-}$ & 0.3 & 26 & 0.044 & 2.74 \\
\hline $\mathrm{CNO}^{-}$ & 0.0007 & 0.03 & 0.080 & 0.81 \\
\hline $\mathrm{SCN}^{-}$ & 0.2 & 1.60 & 0.084 & 0.95 \\
\hline $\mathrm{CN}^{-}$ & 0.0005 & 0.02 & 1.01 & 0.76 \\
\hline $\mathrm{N}_{3}^{-}$ & 0.0012 & 1.51 & 1.12 & 5.60 \\
\hline $\mathrm{HCO}_{3}{ }^{-}$ & 12 & 85 & 0.58 & 0.78 \\
\hline $\mathrm{CO}_{3}^{2-}$ & 15 & 73 & 0.69 & 0.90 \\
\hline $\mathrm{NO}_{3}^{-}$ & 7 & 35 & 0.77 & 0.66 \\
\hline $\mathrm{NO}_{2}^{-}$ & 8.4 & 63 & 0.70 & 2.46 \\
\hline $\mathrm{HS}^{-}$ & 0.0006 & 0.04 & 0.078 & 0.68 \\
\hline $\mathrm{HSO}_{3}^{-}$ & 18 & 89 & 0.91 & $>100$ \\
\hline $\mathrm{SnO}_{3}{ }^{2-}$ & 0.57 & 0.83 & 0.72 & 0.73 \\
\hline $\mathrm{SeO}_{4}{ }^{2-}$ & 118 & 112 & 0.66 & 0.90 \\
\hline $\mathrm{TeO}_{4}{ }^{2-}$ & 0.66 & 0.92 & 0.71 & 3.10 \\
\hline $\mathrm{OsO}_{5}^{2-}$ & 0.92 & 0.95 & 0.80 & 4.93 \\
\hline $\mathrm{P}_{2} \mathrm{O}_{7}^{4-}$ & 25.77 & 48.50 & 16.9 & 9.53 \\
\hline $\mathrm{V}_{2} \mathrm{O}_{7}^{4-}$ & 0.54 & 0.57 & 0.68 & 5.70 \\
\hline $\mathrm{B}_{4} \mathrm{O}_{7}^{2-}$ & 0.64 & 0.95 & 24.3 & 2.24 \\
\hline $\mathrm{ReO}_{4}^{-}$ & 0.11 & 0.75 & 0.65 & 3.47 \\
\hline $\mathrm{RuO}_{4}^{-}$ & 0.101 & 0.69 & 0.65 & 4.51 \\
\hline $\mathrm{S}_{2} \mathrm{O}_{8}{ }^{2-}$ & 0.107 & 0.084 & 0.84 & 3.84 \\
\hline $\mathrm{SeCN}^{-}$ & 0.085 & 0.086 & 0.78 & 0.87 \\
\hline $\mathrm{CS}_{3}{ }^{2-}$ & 0.0087 & 0.0088 & 0.093 & 4.36 \\
\hline $\mathrm{Et}_{2} \mathrm{NCS}_{2}^{-}$ & 0.00079 & 0.0031 & 0.005 & 0.55 \\
\hline $\mathrm{CF}_{3} \mathrm{SO}_{3}^{-}$ & $\mathrm{nt}$ & $\mathrm{nt}$ & $\mathrm{nt}$ & 7.75 \\
\hline
\end{tabular}


(Table 2, continued)

$\begin{array}{lllll}\mathrm{SO}_{4}{ }^{2-} & 63 & >200 & 6.9 & 9.2 \\ \mathrm{ClO}_{4}{ }^{-} & >200 & >200 & >100 & >100 \\ \mathrm{BF}_{4}{ }^{-} & >200 & >200 & >100 & >100 \\ \mathrm{FSO}_{3}{ }^{-} & 0.79 & 0.46 & 15.8 & 9.45 \\ \mathrm{NH}_{\left(\mathrm{SO}_{3}\right)_{2}{ }^{2-}} & 0.31 & 0.76 & 7.1 & 5.96 \\ \mathrm{H}_{2} \mathrm{NSO}_{2} \mathrm{NH}_{2} & 0.31 & 1.13 & 0.12 & 0.008 \\ \mathrm{H}_{2} \mathrm{NSO}_{3} \mathrm{H} & 0.021 & 0.39 & 10.6 & 0.009 \\ \mathrm{Ph}-\mathrm{B}(\mathrm{OH})_{2} & 58.6 & 23.1 & 0.86 & 0.007 \\ \mathrm{Ph}-\mathrm{AsO}_{3} \mathrm{H}_{2} & 31.7 & 49.2 & 0.62 & 0.006\end{array}$

${ }^{\S}$ As sodium salt, except sulfamide, phenylboronic acid and phenylarsonic acid; ${ }^{\#}$ Errors were in the range of $3-5 \%$ of the reported values, from three different assays, by a $\mathrm{CO}_{2}$ hydrase assay method; ${ }^{\mathrm{a}}$ From ref. ${ }^{27}$; ${ }^{\mathrm{b}}$ From ref. ${ }^{33}$; $^{\mathrm{c}}$ This work. 
Table 3

CA class, organism (belonging to the Bacteria, Archaea and Eukarya kingdoms), accession numbers and cryptonyms of the amino acid sequences used to construct the alignment and the phylogenetic tree.

\begin{tabular}{|c|c|c|c|}
\hline CA class & Organism & Accession number & Cryptonim \\
\hline \multirow[t]{6}{*}{ 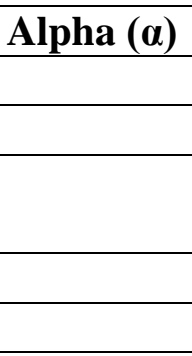 } & Helicobacter pylori J99 & NP_223829..1 & HpylCA_alpha \\
\hline & Homo sapiens, isoform II & AĀH11949.1 & HumCAII_alpha \\
\hline & Homo sapiens, isoform I & NP_001158302.1 & HumCAI_alpha \\
\hline & $\begin{array}{l}\text { Sulfurihydrogenibium } \\
\text { yellowstonense YO3AOP1 }\end{array}$ & ACD66216.1 & SspCA_alpha \\
\hline & Streptococcus salivarius & EIC81445.1 & SsalCA_alpha \\
\hline & Neisseria gonorrhoeae & CAA72038.1 & NgonCA_alpha \\
\hline \multirow[t]{18}{*}{ Beta $(\beta)$} & Schizosaccharomyces pombe & CAA21790 & SpoCA_beta \\
\hline & Brucella suis 1330 & NP_699962.1 & BsuCA_beta \\
\hline & Burkholderia thailandensis & ZP_02386321 & BthCA_beta \\
\hline & Coccomyxa sp. & AAC33484.1 & CspCA_beta \\
\hline & Chlamydomonas reinhardtii & XP_001699151.1 & CreCA_beta \\
\hline & Acinetobacter baumannii & YP_002326524 & AbaCA_beta \\
\hline & Porphyromonas gingivalis & YP_001929649.1 & PgiCA_beta \\
\hline & Myroides injenensis & ZP_10784819 & MinCA_beta \\
\hline & Zea mays & NP_001147846.1 & ZmaCA_beta \\
\hline & Vigna radiata & AAD27876 & VraCA_beta \\
\hline & Flaveria bidentis, isoform I & AAA86939.2 & FbiCA_beta \\
\hline & Arabidopsis thaliana & AAA50156 & AthCA_beta \\
\hline & Helicobacter pylori & BAF34127.1 & HpyCA_beta \\
\hline & Legionella pneumophila & YP_003619232 & LpnCA_beta \\
\hline & Escherichia coli & ACI70660 & EcoCa_beta \\
\hline & $\begin{array}{l}\text { Methanobacterium } \\
\text { thermoautotrophicum }\end{array}$ & GI:13786688 & Cab_beta \\
\hline & Saccharomyces cerevisiae & GAA26059 & SceCA_beta \\
\hline & Dekkera bruxellensis & EIF49256 & DbrCA_beta \\
\hline \multirow{6}{*}{$\begin{array}{l}\text { Gamma } \\
(\gamma)\end{array}$} & Pseudomonas sp. & ZP_10427314.1 & PseCA_gamma \\
\hline & Burkholderia gladioli & YP_004359911.1 & BglCA_gamma \\
\hline & Methanosarcina thermophila & ACQ57353.1 & CAM_gamma \\
\hline & Chlamydomonas reinhardtii & XP_001703237.1 & CreCA_gamma \\
\hline & Arabidopsis thaliana & NP_564091.1 & AthCA_gamma \\
\hline & Porphyromonas gingivalis & YP_001929649.1 & PgiCA_gamma \\
\hline \multirow[t]{5}{*}{ Delta $(\delta)$} & Thalassiosira weissflogii & AAV39532.1 & TweCA_delta \\
\hline & Thalassiosira pseudonana & XP_002287620.1 & TpsCA_delta \\
\hline & Emiliania huxleyi & ABG37687.1 & EhuCA_delta \\
\hline & Bathycoccus prasinos & $\mathrm{CCO} 20234.1$ & Bpr_delta \\
\hline & Lingulodinium polyedrum & ABS87870.1 & LpoCA_delta \\
\hline
\end{tabular}




\begin{tabular}{|c|c|c|c|}
\hline Zeta $(\zeta)$ & Thalassiosira weissflogii & AAX08632.1 & TweCA_zeta,CDCA1 \\
\hline & Micromonas pusilla & XP_003063214.1 & MpuCA_zeta \\
\hline & Thalassiosira oceanica & EJK51395.1 & TocCA_zeta \\
\hline & Thalassiosira pseudonana & XP_002295227.1 & TpseCA_zeta \\
\hline & Micromonas sp. & XP_002504722.1 & MicCA_zeta \\
\hline Eta $(\eta)$ & Plasmodium falciparum 3D7 & PF3D7_1140000 & Pf3D7_eta \\
\hline & Plasmodium reichenowi & CDO65199.1 & Preich_eta \\
\hline & Plasmodium yoelii yoelii $17 \mathrm{X}$ & PY17X_0910400 & Py17X_eta \\
\hline & Plasmodium yoelii yoelii $17 \mathrm{XNL}$ & PY00744 & Py17XNL_eta \\
\hline & Plasmodium vinckei vinckei & KEG02328.1 & Pvvinc_eta \\
\hline & Plasmodium vinckei petteri & EUD73019.1 & Pvpet_eta \\
\hline & Plasmodium berghei ANKA & PBANKA_090900 & PbANKA_eta \\
\hline & Plasmodium chabaudi chabaudi & PCHAS_071030 & Pcchab_eta \\
\hline & ${ }_{25}^{P .}$ falciparum $C A$ (residues 211 to $445^{24,}$ & - & PfCA_eta \\
\hline
\end{tabular}


Fig. 1: "Forced" alignment of the amino acid sequences of the truncated $P$. falciparum CA (PfCA), which contains three additional $\mathrm{C}$-terminal aminno acids (GNK) not present in the native sequence, with the human $\alpha$-CA isoforms I and II (hCA I and hCA II). In order to align the $\mathrm{Zn}(\mathrm{II})$ ion ligands (in red) of the three enzymes, six "missing" residues have to be inserted in the protozoan enzyme sequence, and five in the mammalian enzymes sequences. It may be seen however that the other residues crucial for the catalytic mechanism of the $\alpha$-CAs (i.e., the proton shuttle residue His64 shown in blue) and the gatekeeper residues (Glu106 and Thr199, in orange) are not conserved in the protozoan enzyme (except for Glu106). The hCA I numbering system has been used. ${ }^{29-34}$. Amino acid sequence cryptonym is indicated in Table 3. 
Pf3D7_eta PfIT eta Preich eta Py17x eta Py $17 x \bar{N} L$ eta Pvvinc_eta Pvpet eta PbANKA_eta Pcchab eta
MKLLYLLYP ILLFYNVNVF INYKKSRLMLEMIDKYNTHFVQTTKPYYEFNVTNLTNSKKK MKLLYLLYPILLFYNVNVF INYKKSRLMLEMIDKYNTHFVQTTKPYYEFNVTNLTNSKKK MKLLYLLYP ILLFYNVNVF INYKKSRLMLEMIEKYNTHFVQTTKPYYEFNVTNLSNSKKK -MKHI IFLS IVLCFCDNVMYNNYVERMLFELPNNITDDLNSDP IVEYKIKEKKNDNIDIN -MKHI I FLS IVLCFCDNVMYNNYVERMLEELPNNITDDLNSDP IVEYKIKEKKNDNIDIN -MKHI I FLS IVFCFCDNVVYNNYVGR I LFEFPDNI IHDLSS GP IVEYEIKEHKDDNPDIN -MKHI I LLS IVFCFCDNVVYNNYVARI LFEL PDN I IYDLNSSP IVEYEIKEHKDDNPDIN -MKHI I FLS IVLCFCDNVMYNNYVERI LFEL PNNITDDLNSE PMVEYEVKEKKDDNIDIN -MKHI IFLS IVFCFCDHVVSNNYVGRI LFELPDNIMDDLSSGP IVEYEIKEHKDDNPDIN

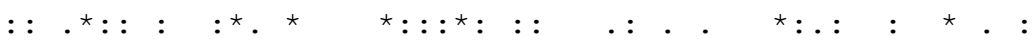

KKKKKRENHLIGSGENMQKKDEKNIKDFH IN------------------------KKKKKRENHLIGSGENMQKKDEKNIKDFHIN-----------------------KKKKKRGNHLIGSGENMQKKDEKH I KDFH IN------------------------KDVRHWDIE INEHKDDPNIQRNIEWHDNNDGNGNNS GNNS GNNNGNNS GNNNDDNNDNDY KDVRHWDIE INEHKDD PNIQRNIEWHDNNDGNGNNS GNNS GNNNGNNS GNNNDDNNDNDY KEVNHWNIEINEHKDNPNIQRNNEGNDDSNNN------------------------KEVRHWNIE INEHKDNPNIQRSNEGNDDSNNN----------------------KDVRHWNIE INEHKDNPNIQRNPEGNDNNHNNENND---------------------KDARHWNIEINGDKDNPNIQRSNEGNDDNNDN------------------------

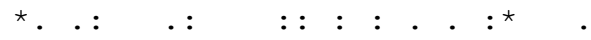

-----------------DYEI DGKT I HNKENKD SFKMNKNKLNDNEELFYMDNILS

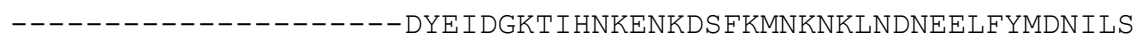
----------------DYE IVGKT I HNKENKDAFKMNKNKLNDNEELFYMDS I LS GNDKNWEYNSNYNDEEFERQNENERDEFSLKNEVEKNSEERKERAFDESNEYADFENMND GNDKNWEYNSNYNDEEFERQNENERDEFSLKNEVEKNSEERKERAFDESNEYADFENMND -----WQYHSNYNDEQSESQNENERNEFS LKNEMEKKPEERKDTQFDKYNEYDDFENMN-----RQYHSNYNDEQSESQNENERNEFS LKNEAEKNTEERKDTQFDKYNEYDNFENMN----NWEYHSNYNDEKFESQNENERNGFS LKNEVEKNPEERKDTPFDEYNEYANEENMN-----WQYHSNYNDKQSESQNENERNEFS LKNEMEKKPEEIKDTQFDKYNEYDDFENVD$:{ }^{\star} \quad::{ }^{\star}::^{\star} \ldots \quad: \quad: \quad:::^{\star} \quad:: \ldots$

------YKPNKKKLFTYSFSENEGNSEKEETLYNFKNMKNIN----------------

-----YKPNKKKLFTYSFSENEGNSEKEETLYNEKNMKNIN---------------

------YKPNKKKLFTYSFSENEGNSEKEETLYNFENRKNIN---------------LENMNNIEKEKKKY FEDMQSKYVEDNTS DGNKEYMGEMKNQQNEYEQNEHQKNEYEQNEH LENMNN IEKEKKKY FEDMQSKYVEDNTSDGNKEYMGEMKNQQNEYEQNEHQKNEYEQNEH ----NNFEENKKKS FEAMQSEDMEDKKGEENKEYAGWAEDKKREDNRDY I DRMDDKNSAG ----NNFEENKKKHFEAMQSEDMEDKKRMDNKEYVDWIEDKQREDNRDYANGMEDKSSAG ----NNFEKNKKKY FEDMQSTYMEDKKNVDNKEYMDEVKNKKIEYQKN-------------NNFEENKRKHFEDMQSEDMEDKKRADNKEYADWIEDKKRSDNRGYTGGMEDKNSAG $:{ }^{\star}:{ }^{*} \quad \star \quad:$. $\quad$ : : :

- - - - - - - -

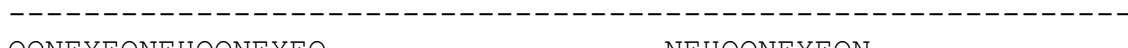

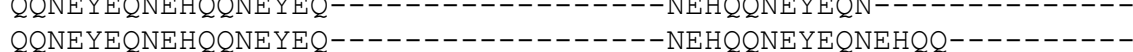
NREYI DGMEYKKEAENKDY I GWVEDKNSAGNRDY IDGMEDKKREENKDYAGWVEDKNSAG NREY I DGMEDKKGEENK----_--------DY I DGMEDKKGEENKDY I GWVEDKNIAG ----------------------------------------------------------NRSYIDGVEDKNSASNK-------------EYISWMDDKNSASNKGYAGWTDDKNGAS

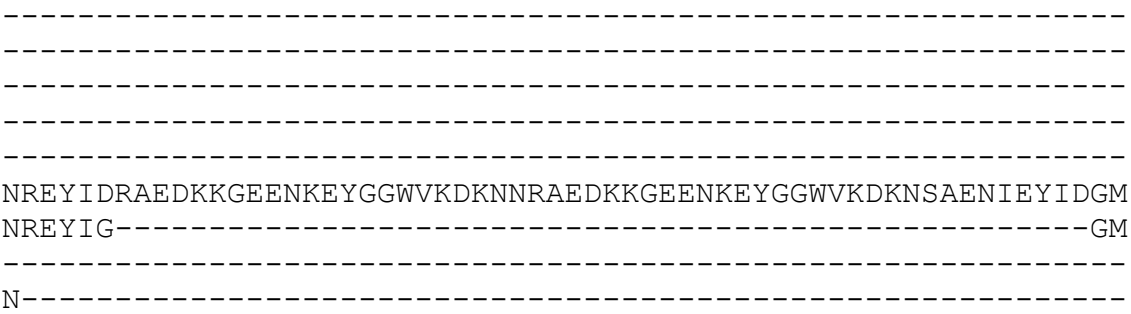


-----------EHQQYEQNEQNEEGNI KNGMIQNNENLS FNYAKHGMDWNVGICKNG -------NEYEQNEHQQYEQNEQNEEGN I KNGMIQNNENLS FNYAKHGMDWNVGICKNG EYKKEAENKEYGGWMGDKQIGSHRKKENNI KSDTTEHNDNLSFEYSKQGMDWAAGICKNG EYKKEAENKEYAGWMNDKQIEDHRNEENNIKSDTTQHNDNLSFDYSKQGMDWAAGVCKNG - - - - - - - - - - - - - - EENNI KNGI I QYNDNLS F DYS KHGMDWNVG ICKNG -------KEYAGWRDDKQIEDHRNEENNTKSDTTQDNDNLSFDYSKQGVNWDVGVCKNG

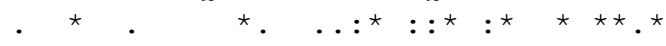

KYQSPVDLPMKDLKERELKNISDVYLNLFDD-DNYAWNNYNKPWMKGDFFYYYEYFIKKI KYOS PVDL PMKDLKERELKNI SDVYLNLFDD-DNYAWNNYNKPWMKGDFFYYYEYFIKKI KYQS PVDLPMKDLKERELKNISDVYLNLFDD-DNYAWNNYNKPWMKGDFFYYYECFIKKI KYQS PVDLHMHTLKERELKNLSDFYLNAFYDNDEYSWNNFNRPWFKGDI FYYYENL INKI KYQS PVDLHMHTLKERELKNLSDFYLNAFYDNDEYSWNNFNRPWFKGDI FYYYENLINKI KYQS PVDLHMHTLKERELKNLSDFYLNAFYDNDENSWNNYNRPWFKGDI FYYYENLVNKI KYQS PVDLHMHTLKERELKNLSDFYLNAFYDNDEYSWNNYNRPWFKGDIFYYYENLINKI KYQS PVDLHMHTLKERELKNLSDFYLNAFYDNDEYSWNNYNKPWFKGDI FYYYENLINKI KYQS PVDLHMHTLKERELKNLSDFYLNAFYDNDEYSWNNYNRPWFKGDI FYYYENL INKI

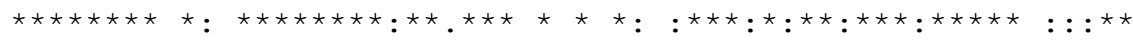

64

9496

VINRQNNIFQ IKAARDG I IPFGVLFTTEQPAMFYADQI HFHAPSEHTFQGSGNRREIEMQ VINRQNNIFQIKAARDG I I PFGVLFTTEQPAMFYADQI HFHAPSEHTFQGS GNRREIEMQ VINRQNNI FQIKAARDG I I F GVLFTTEEPAMFYADQI HFHAPSEHTFQGSGNRREIEMQ I INRQNNMFK IKA SNNE I I F GVLFTTDEPTI FYSHH INFHSPSEHTFEGS GNRRHIEMQ I INRQNNMFK IKASNNE I I PFGVLFTTDE PTIFYSHH INFHSP SEHTFEGS GNRRHIEMQ I INRQNNMFK IKASNNDI I PFGVLFTTDEPAI FYSHH INFHSPSEHTFEGS GNRRHIEMQ I INRQNNMFK IKATNNE I I PFGVLFTTDE PAI FYSHH INFHS PSEHTFEGS GNRRHIEMQ I INRQNNMFKIKASNNE I IPFGVLFTTDEPAI FYSHH INFHS PSEHTFEGS GNRRHIEMQ I INRQNNMFK IKASNNE I I PFGVLFTTDEPAI FYSHH INFHSPSEHTFEGS GNRRHIEMQ

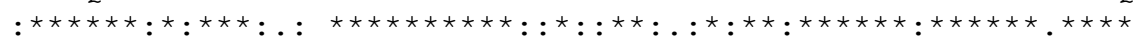

118

IFHSTNYFYDIODDKSKYKKKYGLH I YNNLKKNSKETSKKDSSRYHSYLMSFLMNS LSNE IFHSTNYFYDIQDDKSKYKKKYGLH I YNNLKKNSKETSKKDSSRYHSYLMSFLMNSLSNE IFHSTNYFYDIODDKSKYKKKYGLH IYNNLKKNSKETSKKDSSRYHSYLMSYLMNSLSNE IYHSTNEIYDYDENK---------WNGVFEKKNYKKKNNETNIQHSYILTFLMNSLSNP IYHSTNEIYDYDENK---------WNGVFEKKNYKKKNNETNIQHSYILTFLMNSLSNP IYHSTNE IYDYDESK---------WNGIFGKKKNQKKNNETNIKHSYILTFLRNSLSNP IYHSTNE IYDYDESK---------WNGI FGKKKNOKKNNETNIKHSYILTFLRNSLSNP IYHSTNE IYDYDENK---------WNGVFGKKTYKKKNNETNIQHSYILTFLMNSLSNP IYHSTNEIYDYDESK---------WNGI LGKKKNQKKNNETNIQHSYILTFLRNSLSNP

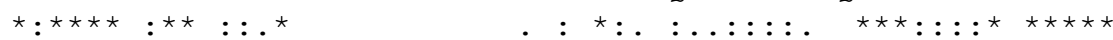

QLQNKYNKKKRIKKMKN---------------QYEVISITFTSAEINASTINAFKK QLQNKYNKKKRIKKMKN-----------------QYEVIS I TFTSAE INAST INAFKK QLQNKYNKKKRIKKMKN-----------------OYEVISITFTSAEINASTINAFKK HLGQQYTKNKKRNKRS KS LYNS IRLDENGKNTKRENQYQVIS ITFS SAE I DKS T INNFKK HLGQQYTKNKKRNKRSKSLYNS IRLDENGKNTKRENQYQVI S ITFS SAE I DKS T INNFKK HLGHQNPKNKKRNKRSK-SYNNTQLGRNGKNTKKLNQYQVIS ITFSSAE INKS T INNFKK RLGHQNPKNKKRNKRSK-SYNNTQLGRNGKNTKRLNQYQVIS ITFS SAE INKST INNFKK HLSQQYTKNKKRNKRSK-SYNS IRMGRNDKNTKRESQYQVI S ITFS SAE I DKS T INNFKK HLGHQNTKNKKRNKRSK-SYNNIQLGRNGKNTKRINQYQVIS ITFSSAE I DNST INNFKK

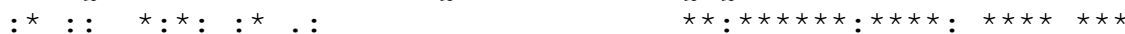

LPSEKFLRT I INVSSAVHVGSDPTLVELKDALNLDALMMMLNIEDMOFLSYOGSSTLPLC LPSEKFLRT I INVSSAVHVGSDPTLVELKDALNLDALMMMLNIEDMQF LSYQGS STLPLC LPSEKF LRT I INVS SAVHVGSDPT LVELKEALNLDALMMMLN IEDMOFLSYOGSSTLPLC LPSEKFLKT I LEAS QNVPVGSDPKLVNLKKPLNLNSLLMMLNMKSMEFFAYHGS STS P DC LPSEKFLKTI LEAS ONVPVGSDPKLVNLKKPLNLNS LLMMLNMKSMEFFAYHGS STS PDC LPSEKFLKT I LEGTQNVPVGSDPTLVDLKAPLNLNSVLMMLNMKSMEFFAYHGSSTS PDC LPSEKFLKT I LEGTQNVPVGSDPTLVDLKAPLNLNSVLMMLNMKSMEFFAYHGSSTSPDC LPSEKFLKT I LEGSONVPVGSGPKLVNLKE PLNLNS LLMMLNMKSMEFFAYHGSSTSPGC LPSEKFLKT I LEGTQNI PVGSDPTLVDLKVPLNLNSVLMMLNMKSMEFFAYHGSSTTPDC

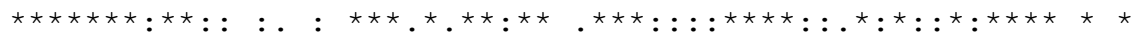

DENVSWKVAKQPLPVSTETILNFYYLLKKHTPNYSGSDNDNYRSLQNVEDNTRHYRKFSL DENVSWKVAKQPLPVSTETI LNFYYLLKKHTPNYSGS DNDNYRS LQNVEDNTRHYRKFSL DENVSWKVAKQPLPVSTETI LNFYYLLKKHTPNYSGS DNDNYRSLQNVEDNTRHYRKFSL NENVHWKVAKKS L P ISTE TMLKFYNMLKKTTPDYNAS DNDNFRALQNVQGNI HNYGRVYL NENVHWKVAKKSLPISTETMLKFYNMLKKTTPDYNAS DNDNFRALQNVQGNI HNYGRVYL 
NENVHWKVAKKSLPISTETMLKFYNMLKKTTPDYNGS DNDNFRALQNVQGNI HNYGRVYL NENVHWKVAKKS LP ISTETMLKFYNMLKKTTPDYNGS DNDNFRALQNVQGNI HNYGRVYL NENVHWKVAKKS LP ISTETMLKFYNMLKKTTPYYNAS DNDNFRALQNVQGNI HNYGRVYL SENVHWKVAKKSLP ISTETMLKFYNMLKKTTPDYNS S DNDNFRALQNVQGNVHNYGRVYL

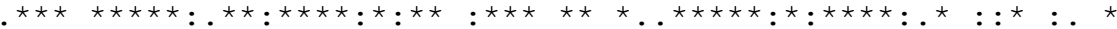

VQVFPIQVLISSAISNIEDKKVINIIKDISPKNMSFTYYSKWDIYFILFIFYNIVLFLF VQVFP IQVLISSA I SNIEDKKVINI IKDIS PKNMSF SYYSKWDIYF ILF I FYNIVLFLF VQVFPIQVLISSA ISNVEDKEVINI IKDISPKNMSFSYYSKWDIYFILFIFYNIVLFLF IQGFPVQLLISSALTTSEDKNVIENIKLAYSKSS GNY I YFNLIFLLLI FMFLQNY---IQGEPVQLLISSALTTSEDKNVIEN IKLAYSKSS GNY IYFNLI FLLL IFMFLQNY---IQGFPVQLLISS I LTTSEDKTVIENIKQAYSKSNGNY ICFNF I FLLLI F I FLQNYIQGFPVQLLISS ILTTSEDKTVIEN I KQAYSKSNGNY ICFNF I FLLLI FMFLQNY---IQGF PVQLLISSALMTSDDKNVIENI KLAYSKS SANY I YFNF IFLLLI FMFLQNY---IQGF PVQLLISS ILTTSEDKTVIENI KQAYSKSNGNY I YFNF I FLLLIFMYLQNY----

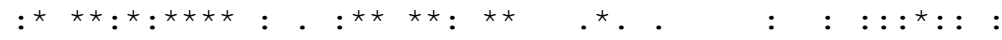

Figure 2: Alignment of Plasmodium putative CA amino acid sequences. which demonstrate the existence of a new CA family, denominated $\eta$-CA class. The presumed $\mathrm{Zn}$ (II) ligands are at positions $x, x+2$ and $x+24$. Amino acid sequence cryptonym is indicated in Table 3 . 


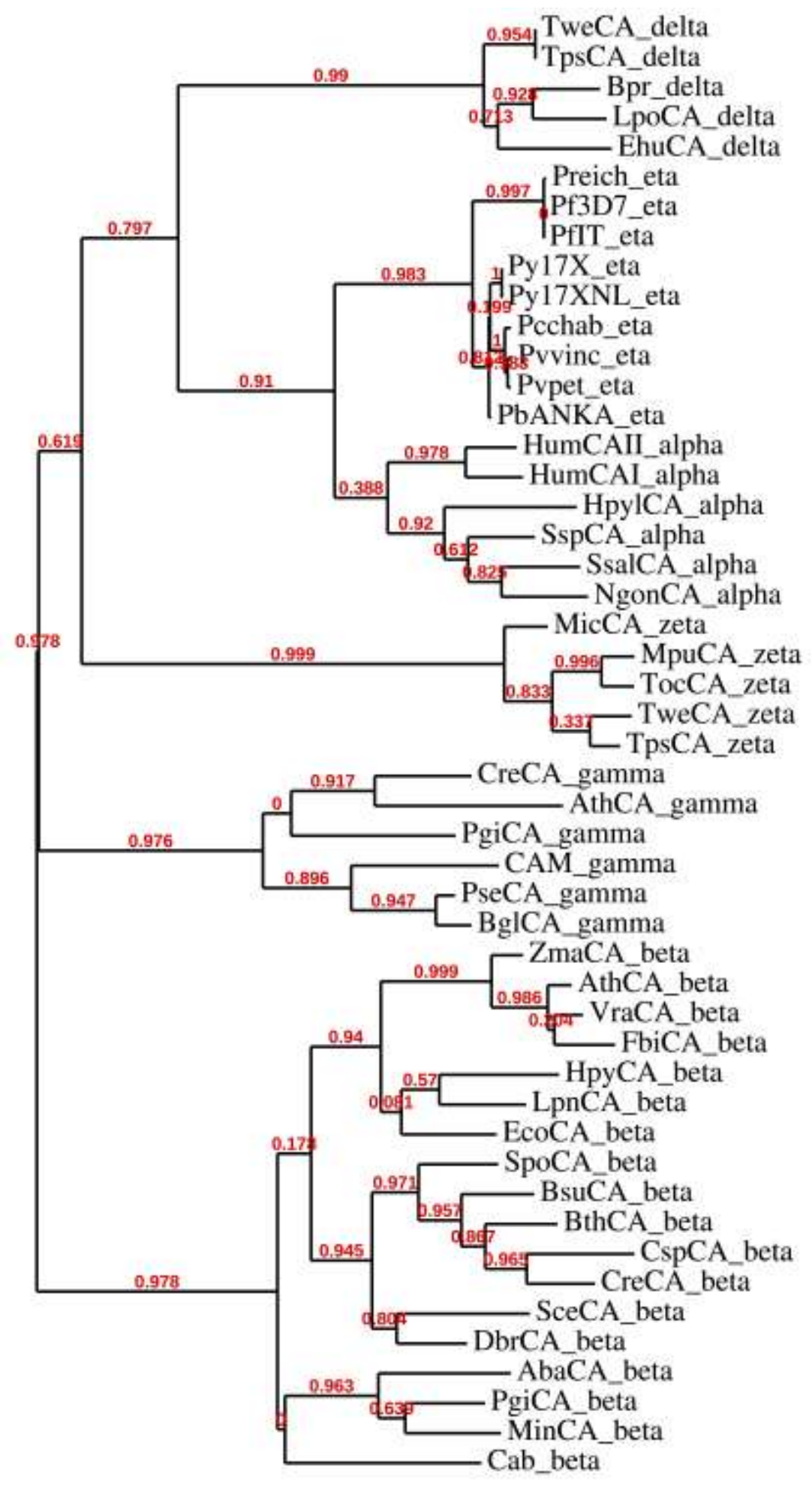

Fig. 3: Phylogenetic tree leading to the discovery of the $\eta$-CA genetic family in Plasmodia and constructed using amino acid sequences of the $\alpha-, \beta-, \gamma-, \delta-, \zeta$ - and $\eta$-CAs from selected prokaryotic and eukaryotic species. The tree was created using the program PhyML 3.0. Branch support values have been reported at branch points. Class, organisms, accession numbers and cryptonyms of the sequences used in the alignment have been indicated in Table 3. 